\title{
Multimodal Translation: Is Translation only Verbal?
}

\author{
Shubhangi Shrinivas Rao \\ (D)/0000-0002-1939-5503 \\ PhD Scholar, Shri Govind Guru University, Godhra, Gujarat, India \\ Assistant Professor of English, Shri Indubhai Sheth Law College, Dahod, India \\ DOI: $h$ ttps://dx.doi.org/10.46679/978819484830106
}

\begin{abstract}
This chapter is based on the Multimodal theory of translation. Although the practice of translation is long-established, the study developed into an academic discipline much later as of the second half of the twentieth century. Before that translation had normally been the element of language learning which was dominated by the Grammar translation method centered on the role study of the grammatical rules and structures of foreign language. The Romantic approach of originality of work has always denied the study of translation as a discipline. The original character of the text has tampered with when it is translated. The idea of Mimesis given by Plato and Aristotle stating all arts as imitative clearly would deny the systematic study of translation.
\end{abstract}

Translation was considered a part of comparative literature but it gained recognition as a separate discipline of study only after the mid-twentieth century along with the emergence of various other disciplines like cultural studies, gender studies, postcolonial studies etc. Since translation studies emerged as an academic discipline, there have been questions about the equivalence of translation from one language to another. But there are also instances in which translation according to the culture is said to be an art in itself. Looking from another perspective, translation from one text to another is entirely 
dependent on the semantic side of the text which is why a broader study of translation studies can be done in the form of Multi-modality of translation or Inter-medial translation. This inter-medial translation may include the source text in any art form such as films, adaptation, music, dance, sculptures, dubbing, subtitles, paintings and many more. This chapter would focus briefly on translation studies as a discipline in itself, the issues of equivalence and untranslatability and challenge these issues in the form of studying and analyzing various modes in translation.

Keywords: Multimodality, inter semiotic, ekphrasis, audio-visual, transcreation, equivalence, untranslatability.

\section{What is Translation?}

To translate means to carry across. Dr. Johnson states: "To translate is to change into another language, retaining the sense." Translation is a process of communication involving a sender and a receiver. It is a process of communication that involves two languages in which the translator acts as a mediator. Translation is a bilingual process of communication ordinarily aiming at the production of a target language text equivalent to a source-language text.

The term translation has several meanings: it can refer to the general subject field, the product or the process. Although the practice of translation is long-established, the study developed into an academic discipline much later as of the second half of the twentieth century. Before that translation had normally been the element of language learning which was dominated by the Grammar translation method centered on the role study of the grammatical rules and structures of foreign language.

In the USA, translation was promoted in the 1960 s by the translation workshop concept based on I.A. Richard's reading workshops and practical criticism approach. These workshops were intended as a platform for the introduction of new translations into the 


\section{This is a limited preview of the chapter.}

To read the full-text chapter, get access by purchasing this chapter or consider buying the complete book. If your library has subscription to EBSCOhost, the chapter including other chapters of the book can be accessed through your library.

This chapter is a part of the book, 'Contemporary Translation Studies' ISBN (paperback): 978-81-948483-0-1; ISBN (ebook): 978-81-948483-8-7

Book DOI: https://dx.doi.org/10.46679/9788194848301 
subjective. It is not possible to bridge the gap between verbal and visual yet multimodal translation makes the juxtaposition of visual art and the medium of writing which shows how both media can deliver the same message.

The multimodal translation is a step beyond traditional translation which can offer a wide range of interdisciplinary studies possible via the art of translation. It is time that translation studies as a discipline should break free from the limitations of equivalences and untranslatability which makes it secondary to any original text. The cultural turn in translation offered an approach to focus on the meaning-making process in translation but the question of untranslatability also arise from this cultural context. There is a need to only emphasize the meaning of the text and the accuracy to be evaluated by the audience's interpretation of the same text. This approach of multimodality will open new spheres for translation studies as a discipline.

\section{References}

Baer, Brian James, "From Cultural Translation to Untranslatability:

Theorizing Translation Outside Translation Studies." Alif:

Journal of Comparative Poetics, no. 40, 2020, pp. 139-163. JSTOR, www.jstor.org/stable/26924869.

Bassnett, Susan. Translation Studies. London: Routledge, 1980

Cesar Dominguez, Haun Saussy and Dario Villueva, “ Interartistic

Comparisons" in Introducing Comparative Literature: New Trends and Applications, 2015, 107-124.

Chuang, Ying-Ting. (2006). Studying subtitle translation from a multimodal approach. Babel. 52. 10.1075/babel.52.4.06chu.

Damaskinidis, George. (2016). The Visual Aspect of Translation Training in Multimodal Texts.

Eubanks, Paula K. “ Art is a Visual Language.” Visual Arts Research, 
vol. 23, no. 1, 1997, pp. 31-35. JSTOR,

www.jstor.org/stable/20715892.

GN Devy, "Translation Theory: an Indian Perspective”, In Another

Tongue: Essays on Indian English Literature. 1993

Haas, W. "The Theory of Translation." Philosophy, vol. 37, no. 141,

1962, pp. 208-228. JSTOR, www.jstor.org/stable/3748438.

Hyde, George M. "LITERARY TRANSLATION.” Hungarian Studies in

English, vol. 22, 1991, pp. 39-47. JSTOR, www.jstor.org/stable/41273850.

Kaul, H.K. "Literature in Translation A Report on an International Conference." India International Centre Quarterly, vol. 11, no. 2, 1984, pp. 243-256. JSTOR, www.jstor.org/stable/23001663.

Kress, G, \& Van Leeuwen, T. (1996) 2006. Reading Images: The Grammar of Visual Design. London: Routledge.

Kress, G. (2010). Multimodality: A Social Semiotic Approach to

Contemporary Communication. New York, NY: Routledge.

Luis Perez Gonzalez, "Multimodality in translation and Interpreting

Studies: Theoretical and Methodological Perspectives", A

Comparison to Translation Studies. Eds. Sandra Bermann and

Catherine Porter, 2014, 119-132.

Mujiyanto, Yan \& Fitriati, Sri. (2019). Multimodality in Audio-Verbo

Visual Translation. KnE Social Sciences.

10.18502/kss.v3i18.4765.

Munday, Jeremy. ed. The Routledge Companion to Translation Studies,

Routledge, 2009.

Music as Multimodal Discourse: Semiotics, Power and Protest. London

\& New York: Bloomsbury Academic, pp.1-20.

Reading poetry through art (I): W.H. Auden's 'Musee des beaux arts' \&

William Carlos Williams' 'Landscape' (hyperbolit.com)

Tewfik, Lamia. (2015). Sculpting with Words: From Ekphrasis to Interart Translation.

Tuominen, T., Jiménez Hurtado, C. and Ketola, A. (2018) Why methods 
matter: approaching multimodality in translation research. Linguistica Antverpiensia: New Series - Themes in Translation Studies, 17, pp. 1-21.

Venuti, Lawrence. Ed. The Translation Studies Reader. London: Routledge, 2000

Zamora, Lois Parkinson. "Interartistic Approaches to Contemporary Latin American Literature." MLN, vol. 114, no. 2, 1999, pp. 389415. JSTOR, www.jstor.org/stable/3251554.

\section{Images credit:}

https://hyperbolit.files.wordpress.com/2020/10/pieter_bruegel_de_oude__de_val_van_icarus.jpg https://media.gettyimages.com/vectors/pictured-cartoon-texts-of-the-comic-book-soundsvector-id165924536?s=612x612 https://mir-s3-cdn-cf.behance.net/project_modules/disp/380d10100378317.5f076d1a69609.jpg https://th.bing.com/th/id/OIP.hLo_3CGiHzGraA_mtmJstwHaEA?w=299\&h=180\&c=7\&o=5\&pid=1 .7 https://th.bing.com/th/id/R.00265c3cb7a9e12341f55005bb262ead?rik=NhLdN63J8WoVYQ\&riu= http\%3a\%2f\%2f1.bp.blogspot.com\%2f_iRkmKzcx1xo\%2fTSnaVKXdgJI\%2fAAAAAAAAABk\%2fPi K5HpRlfJg\%2fs640\%2funtitled.bmp\&ehk=DkXAa\%2fA\%2b2YNuQ\%2fUBpvGBCPMguQCTquqLF8 SCsDSqfjU\%3d\&risl=\&pid=ImgRaw https://th.bing.com/th/id/R.bb4b9e3a842359d6d31a2952481ac1e7?rik=1s6e52SCHi3Frg\&riu=htt p\%3a\%2f\%2fwww.jackdevant.com\%2fwp-content\%2fuploads\%2f2016\%2fo5\%2fJack-DevantRomeo-and-Juliet-Balcony114.jpg\&ehk=7mkAcL9qeGPrmnYt3Rqluak6jWGc0K009Pqq11VnWWg\%3d\&risl=\&pid=ImgRaw https://www.barnorama.com/wp-content/images/2015/01/bizarre_subtitles/09bizarre_subtitles.jpg 
